\title{
Kemampuan Pemahaman Konsep Siswa Kelas VII SMPN 4 Batang Gansal dalam Menyelesaikan Masalah Matematika
}

\author{
Puji Astuti \\ STKIP Insan Madani Airmolek \\ pujiastuti2695@gmail.com
}

\begin{tabular}{|l|l|l|l|}
\hline Received: $10-06-2020$ & Revised: $10-04-2021$ & Accepted: 01-05-2021 & Published: 06-06-2021 \\
\hline
\end{tabular}

\begin{abstract}
ABSTRAK
Penelitian ini bertujuan untuk mendeskripsikan kemampuan pemahaman konsep siswa dalam menyelesaikan masalah matematika. Jenis penelitian ini adalah deskriptif kualitatif. Subjek dalam penelitian ini adalah siswa kelas VII SMPN 4 Batang Gansal. Teknik pengumpulan data dalam penelian ini menggunakan pengamatan, tes pemahaman konsep matematika siswa. Hasil penelitian diperoleh (1) Siswa belum memenuhi indikator pertama dan ketiga pemahaman konsep. Pada indikator pertama, siswa kurang dalam menyebutkan sifat persegi panjang dan jajargenjang secara detail, sedangkan pada indikator ketiga siswa kurang teliti dalam melakukan operasi perkalian. (2) siswa telah memenuhi indikator kedua pemahaman konsep. Hal ini terlihat dari jawaban siswa yang mampu menyebutkan contoh kontra dari konsep yang telah dipelajari.
\end{abstract}

Kata Kunci : Kemampuan Pemahaman Konsep, Masalah Matematika.

\begin{abstract}
This study aims to describe the ability to understand student concepts in solving mathematical problems. This type of research is descriptive qualitative. The subjects in this study were VII grade students of SMPN 4 Batang Gansal. Data collection techniques in this study used observation, tests of students' understanding of mathematical concepts. The results obtained (1) Students have not met the indicator of understanding the first and third concepts. In the first indicator, students do not mention the nature of the rectangle and the level of the stairs in detail, whereas in the third indicator the students are not careful in doing multiplication operations. (2) students have fulfilled the second indicator of concept understanding. This can be seen from the answers of students who are able to cite examples of counter concepts that have been learned.
\end{abstract}

Keywords: Concept Understanding Ability, Mathematical Problems

\section{PENDAHULUAN}

Matematika merupakan salah satu mata pelajaran yang diajarkan mulai dari jenjang pendidikan dasar sampai pendidikan tinggi. Hal ini menunjukkan pentingnya peranan matematika dalam dunia pendidikan dan kehidupan. Pembelajaran matematika di sekolah dasar merupakan dasar bagi penerapan konsep matematika pada jenjang berikutnya. Pembelajaran matematika perlu dibuat semenarik mungkin agar dapat merangsang pemikiran, ide-ide, prinsip dan konsep-konsep materi yang dapat mengembangkan 
keterampilan siswa dalam berpikir maupun merancang sesuatu, sehingga siswa menjadi insan yang produktif di masa datang.

Pembelajaran matematika di SMP memiliki tujuan agar siswa memiliki kemampuan memahami konsep matematika, menjelaskan keterkaitan antar konsep, dan mengaplikasikan konsep atau algoritma secara luwes, akurat, efesien dan tepat dalam pemecahan masalah. Pembelajaran matematika pada dasarnya adalah suatu proses belajar mengajar yang dibangun oleh guru untuk mengembangkan kreativitas berpikir siswa, serta dapat mengkonstruksi pengetahuan baru sebagai upaya meningkatkan penguasan yang terbaik terhadap materi matematika (Susanto, 2015).

Tujuan pembelajaran matematika untuk sekolah menengah lainnya yaitu menuntut penguasaan matematika tidak hanya sebatas penguasaaan fakta dan prosedur matematika serta pemahaman konsep, tetapi juga berupa kemampuan proses matematika siswa. Semuanya harus saling menunjang dalam proses pembelajaran matematika sehingga akan membentuk siswa secara utuh dalam menguasai matematika. Pemahaman terhadap suatu konsep sangat penting karena apabila menguasai konsep materi prasyarat maka siswa akan mudah untuk memahami konsep materi selanjutnya (Kusumaningtyas, 2013).

Salah satu kemampuan yang harus dimiliki siswa adalah kemampuan pemahaman konsep, karena pemahaman konsep memberikan manfaat yang besar kepada siswa dalam melihat pemahaman konsep dasar. Kemampuan pemahaman konsep merupakan kemampuan dimana siswa berupaya memahami konsep yang diberikan oleh guru. Dalam psikologi Gestalt suatu konsep yang penting adalah tentang "insight" yaitu pengamatan dan pemahaman terhadap hubungan-hubungan antar bagian-bagian suatu situasi permasalahan (Sagala, 2006).

Pemahaman konsep merupakan suatu aspek yang sangat penting dalam pembelajaran, karena dengan memahami konsep siswa dapat mengembangkan kemampuannya dalam setiap materi pelajaran. Pemahaman dapat diartikan menguasai sesuatu dengan pikiran. Pemahaman berasal dari kata paham yang artinya "mengerti benar". Meletakkan hal tersebut dalam hubungannya satu sama lain secara benar dan menggunakannya secara tepat pada situasi.

De block (dalam Winkel, 2004) mendefinisikan konsep adalah suatu arti yang memiliki sejumlah objek yang bercirikan sama, dalam bentuk lambing mental yang penuh gagasan. Sedangkan Zack \& Tversky (dalam Santrock, 2007) mengemukakan bahwa konsep adalah kategori-kategori yang mengelompokkan objek, kejadian, dan karakteristik berdasarkan properti umum. Menurut Teori Ausubel (dalam Bahar, 2012) individu 
memperoleh konsep melalui dua cara yaitu: pertama, melalui formasi konsep. Formasi konsep merupakan proses pembentukan konsep secara induktif dan merupakan suatu bentuk belajar menemukan melalui proses diskruminatif, abstraktif, dan diferensiasi. Kedua asimilasi konsep. Asimilasi konsep menyangkut cara bagaimana siswa dapat mengaitkan informasi atau materi pelajaran dengan struktur kognitif yang telah ada.

Konsep menurut Hamalik (2008) adalah suatu kelas atau kategori stimuli yang memiliki ciri-ciri umum. Konsep merujuk pada pemahaman dasar. Siswa mengembangkan suatu konsep ketika mereka mengklasifikasikan atau mengelompokkan benda-benda atau mengasosiasikan nama dalam suatu kelompok tertentu. Konsep akan muncul dalam berbagai konteks, sehingga pemahaman konsep akan terkait dalam berbagai situasi. Pemahaman konsep adalah tingkat kemampuan yang mengharapkan siswa memahami konsep, situasi, dan fakta yang diketahui serta dapat menjelaskan dengan kata-kata sendiri sesuai dengan pengetahuan yang dimilikinya dengan tidak merubah artinya.

Pemahaman konsep adalah penguasaan sejumlah materi pembelajaran, dimana siswa tidak sekedar mengenal dan mengetahui, tetapi mampu mengungkapkan kembali konsep dalam bentuk yang lebih dimengerti serta mampu mengaplikasikannya (Putri, 2012). Menurut Fadhila (2014) kemampuan pemahaman konsep merupakan kemampuan siswa untuk dapat mengerti konsep yang diajarkan guru. Lebih lanjut menurut Fadhila kemampuan siswa dalam menjelaskan konsep yang telah dipelajari dengan menggunakan kata-kata sendiri. Sedangkan menurut Hendriana (2017) pemahaman konsep matematis merupakan kemampuan yang harus diperhatikan selama proses pembelajaran matematika terutama untuk memperoleh pengetahuan matematika yang bermakna. Berdasarkan uraian di atas, dapat disimpulkan pemahaman konsep adalah kemampuan yang dimiliki oleh seorang siswa untuk mengemukakan kembali ilmu yang diperolehnya baik dalam bentuk ucapan maupun tulisan kepada orang lain sehingga orang tersebut benar-benar mengerti apa yang disampaikan.

Badan Nasional Standar Pendidikan (BSNP) (2006), menyebutkan indikator yang menunjukkan pemahaman konsep antara lain: (1) Menyatakan ulang sebuah konsep; (2) Mengklasifikasikan objek-objek menurut sifat-sifat tertentu (sesuai dengan konsepnya); (3) Memberi contoh dan non-contoh dari konsep; (4) Menyajikan konsep dalam berbagai bentuk representasi matematis; (5) Mengembangkan syarat perlu atau syarat cukup suatu konsep; (6) Menggunakan, memanfaatkan, dan memilih prosedur atau operasi tertentu; dan (7) Mengaplikasikan konsep atau algoritma pemecahan masalah. 
Agustina (2016) menyebutkan indikator pemahaman konsep sebagai berikut: (1) Menyatakan ulang sebuah konsep; (2) Memberi contoh dan bukan contoh; (3) Mengaplikasikan konsep dalam memecahkan masalah. Indikator pemahaman konsep yang digunakan dalam penelitian ini yaitu (1) Mampu menerangkan secara verbal mengenai apa yang telah dicapainya; (2) Mampu memberikan contoh kontra dari konsep yang telah dipelajari; (3) Mampu mengembangkan konsep yang telah dipelajari.

Berdasarkan observasi pada proses pembelajaran di Kelas VII SMP Negeri 4 Batang Gansal ditemukan kurangnya kemampuan siswa dalam menerangkan secara verbal mengenai konsep yang telah dicapainya, kurangnya kemampuan siswa dalam memberikan contoh kontra dari konsep yang telah dicapainya, dan kurangnya kemampuan mengembangkan konsep yang telah dipelajarinya. Dari hasil wawancara dengan siswa diketahui bahwa pemahaman konsep siswa terhadap apa yang telah dipelajari masih sangat kurang. Dampak dari hal tersebut akan mempengaruhi hasil belajar siswa.

Berdasarkan permasalahan diatas, dapat disimpulkan bahwa perlu adanya suatu gambaran tentang pemahaman konsep siswa. Hal ini sejalan dengan penelitian yang dilakukan oleh Fitria, Mega dkk (2019) tentang Analisis Kemampuan Pemahaman Konsep Matematis Siswa Yang Menggunakan Model Pembelajaran Reciprocal Teaching bahwa kemampuan pemahaman konsep sangat diperlukan dalam matematika, dengan adanya deskripsi tentang pemahaman konsep siswa maka guru dapat melakukan suatu upaya untuk meningkatkan pemahaman konsep. Salah satu upaya yang digunakan adalah dengan menggunakan model-model pembelajaran tertentu.

Sejalan dengan itu penelitian yang dilakukan Ruslan dkk (2017) tentang Deskripsi Pemahaman Konseptual Matematika Siswa SMP IT Wahdah Islamiyah pada Materi Pecahan Ditinjau dari Gaya Belajar Visual menyatakan bahwa pendekripsian pemahaman konsep siswa berguna untuk mengetahui sebarapa besar siswa menguai suatu materi dan untuk meningkatkan pemahaman konsep tersebut diperlukan suatu model pembelajaran.

\section{METODE PENELITIAN}

Jenis penelitian ini adalah penelitian deskriptif kualitatif. Creswel (2010) menyatakan bahwa penelitian kualitatif adalah metode penelitian yang digunakan untuk mengeksplorasi dan memahami makna dari sejumlah individu atau kelompok. Penelitian ini dilakukan untuk mendeskripsikan kemampuan pemahaman konsep siswa kelas VII SMPN 4 Batang Gansal dalam Menyelesaikan Masalah Matematika. Subjek dalam penelitian ini adalah siswa kelas VII SMPN 4 Batang Gansal. Teknik pengumpulan data 
dalam penelian ini menggunakan pengamatan, tes pemahaman konsep matematika siswa. Dalam menganalisis data peneliti mengacu pada Miles dan Huberman yaitu memilih data, mempresentasikan dan menarik generalisasi.

\section{HASIL DAN PEMBAHASAN}

Penelitian deskriptif tentang kemampuan pemahaman konsep siswa menunjukan pada indikator pertama kemampuan siswa menerangkan secara verbal mengenai apa yang telah dicapai dapat terlihat dari jawaban siswa dalam mengerjakan soal tes kemampuan pemahaman konsep, seperti yang ditunjukkan pada Gambar 1.

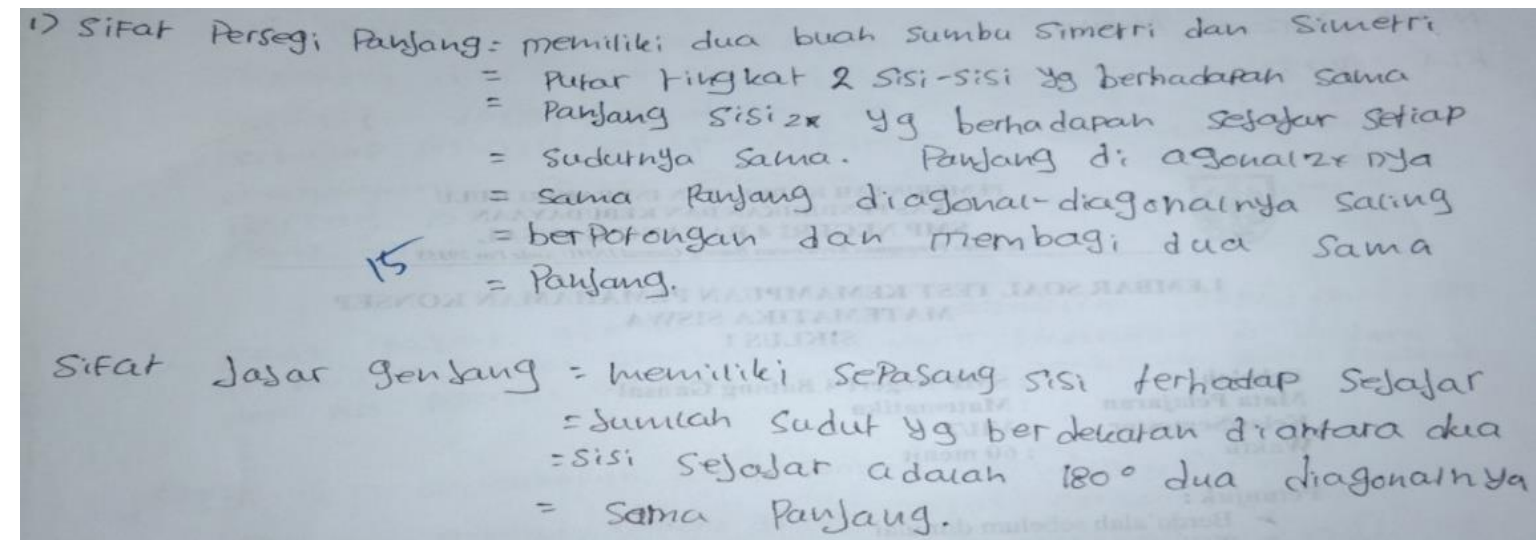

Gambar 1. Jawaban Siswa dalam Menerangkan Secara Verbal Mengenai Apa yang Telah Dicapainya

Berdasarkan Gambar 1 terlihat bahwa dari jawaban siswa telah menyebutkan secara verbal mengenai apa yang telah dicapainya. Hal ini diketahui dari siswa mampu menyebutkan sifat persegi panjang dan sifat jajar genjang. Secara umum siswa telah mampu menyebutkan sifat-sifat dari kedua bangun datar tersebut, namun masih belum lengkap. Sebaiknya dalam penulisan sifat-sifat tersebut siswa membuatnya dalam bentuk poin-poin, sehingga memudahkan bagi pembaca untuk memahami maksud jawaban siswa. Ketika siswa diminta untuk menerangkan secara verbal hasil pekerjaannya mereka mampu menjelaskannya dengan baik.

Menurut sanjaya (2009) salah satu indicator kemampuan pemahaman konsep matematika adalah mampu menerangkan secara verbal mengenai apa yang telah dicapainya. Artinya siswa dituntut untuk dapat menyampaikan secara verbal mengenai apa yang telah dicapainya (Fitria, Kartasasmita, \& Supianti, 2019; Suwarman, 2018). Dengan demikian siswa tidak hanya dituntut memahami materi semata tetapi siswa juga dituntut untuk menyampaikan hasil dari pemikirannya. 
Pada indikator kedua kemampuan pemahaman konsep yaitu mampu memberikan contoh kontra dari konsep yang telah dipelajari terlihat siswa mampu memberikan contoh kontra. Hal ini dapat terlihat dari jawaban siswa pada Gambar 2.

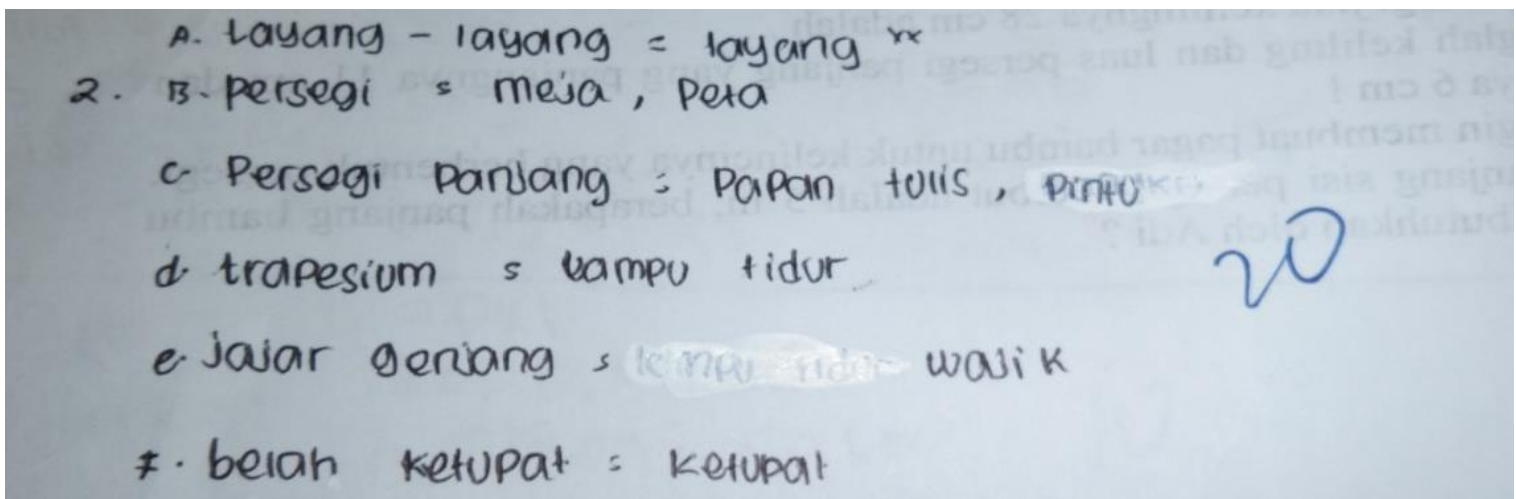

Gambar 2. Jawaban Siswa dalam Memberikan Contoh Kontra dari Konsep yang Telah Dipelajari

Berdasarkan Gambar 2 siswa sudah mampu menjawab soal dengan baik dan benar. Terlihat jawaban siswa dalam memberikan contoh kontra dari konsep yang telah dipelajarinya. Selain mempelajari konsep matematika siswa juga dapat menerapkan konsep tersebut dalam kehidupan sehari-hari. Ketika siswa diminta untuk menunjukkan matematika yang ada dalam kehidupan sehari-hari siswa mampu menunjukkanya. Selain konsep bangun datar masih banyak konsep matematika yang ada dalam kehidupan seharihari seperti pada kegiatan jual beli.

Menurut Dafril (2011) Kemampuan memberi contoh dan bukan contoh adalah kemampuan siswa untuk dapat membedakan contoh dan bukan contoh dari suatu materi. Contoh: siswa dapat mengerti contoh yang benar dari suatu materi dan dapat mengerti yang mana contoh yang tidak benar

Pada indikator ketiga kemampuan pemahaman konsep yaitu mampu mengembangkan konsep yang telah dipelajari. Hal ini terlihat dari soal pemahaman konsep siswa yang pertanyaannya adalah Heru akan membuat layang-layang yang panjang diagonalnya $25 \mathrm{~cm}$ dan $24 \mathrm{~cm}$, hitunglah luas karton yang dibutuhkan Heru!. Berikut jawaban siswa pada indicator 3 pemahaman konsep, ditunjukkan pada gambar 3 . 


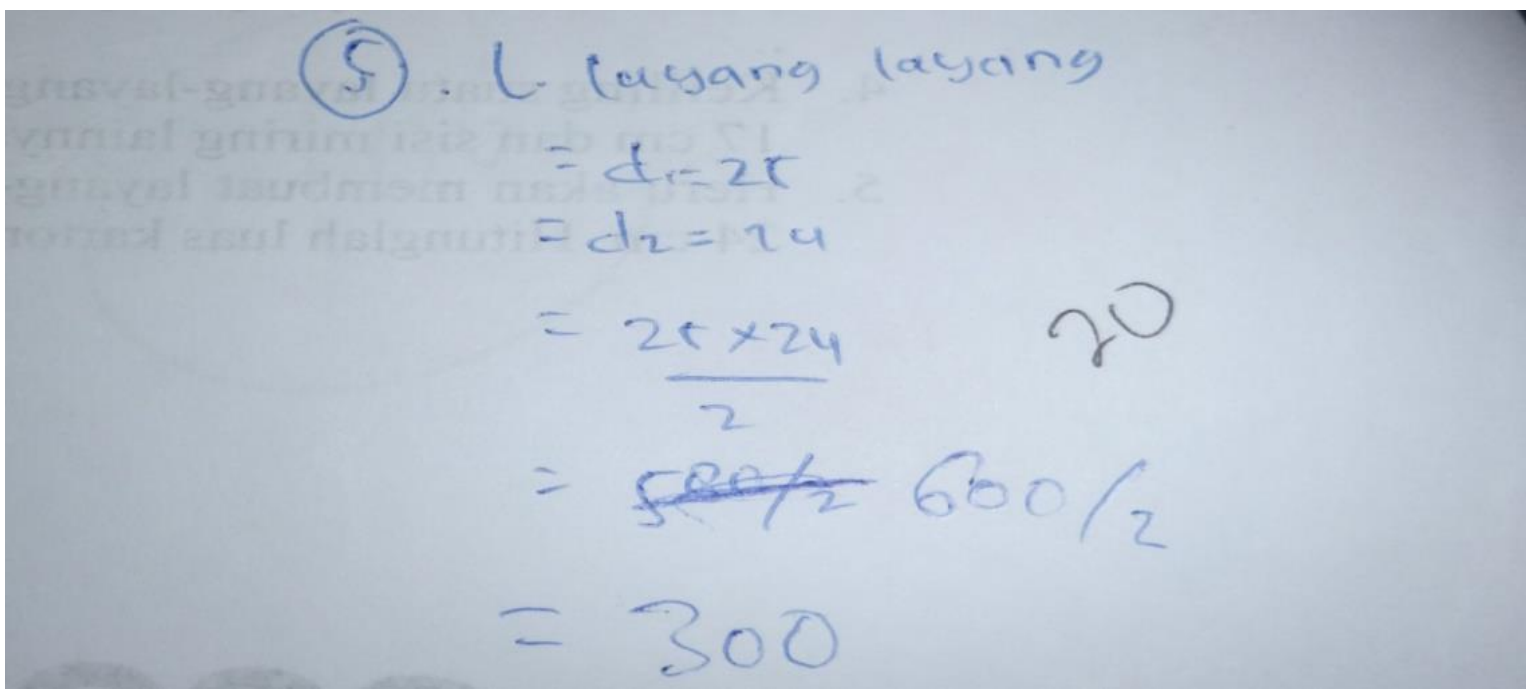

Gambar 3. Jawaban Siswa dalam Mengembangkan Konsep yang Telah Dipelajari

Pada Gambar 3 di atas terlihat bahwa siswa telah mampu mengembangkan konsep yang telah dipelajari. Jawaban siswa sudah benar, namun terdapat sedikit kesalahan dalam perkalian, hal ini dikarenakan kurang teliti dalam mengerjakan perkalian. Siswa telah mengetahui rumus untuk menentukan luas layang-layang. Namun tidak dituliskan dengan jelas rumus tersebut. Dari jawaban siswa tersebut terlihat bahwa siswa langsung menuliskan diagonalnya. Mengalikan kedua diagonalnya lalu membagi dua.

Menurut Agustina (2016) salah satu indikator kemampuan pemahaman konsep matematis adalah mampu mengembangkan konsep yang telah dipelajari. Maksudnya teori belajar matematika pertama yang harus diingat adalah bahwa belajar matematika berarti memahami konsep untuk setiap soal yang dihadirkan. Walau di dalam matematika ada rumus yang harus dihapal, namun inti dari pelajaran matematika adalah pemahaman. Seberapa hebat anda dalam menghafal berbagai rumus matematika, tidak akan bermanfaat jika konsep dasarnya tidak dipahami. Pemahaman konsep menjadi modal utama dalam menguasai pelajaran matematika. Itulah teori belajar matematika yang paling utama yang harus dikuasai terlebih dahulu.

Jika dilihat dari pekerjaan tersebut siswa telah mengerti konsepnya. Ketika dihadapkan pada soal cerita sebaiknya guru memberikan siswa arahan bagaimana menyelesaikan soal tersebut. Karna sejatinya ketika siswa mengerjakan soal dalam bentuk cerita, pengerjaanya akan berbeda dengan ketika siswa mengerjakan soal rutin.

Di dalam matematika itu sendiri, terdapat dua jenis soal, yaitu tentang masalah rutin dan masalah non-rutin. Masalah rutin biasanya mencakup aplikasi suatu prosedur matematika yang sama atau mirip dengan hal yang baru dipelajari, sedangkan dalam 
masalah tidak rutin, untuk sampai pada prosedur yang benar diperlukan pemikiran yang lebih mendalam.

Masalah non-rutin lebih kompleks daripada masalah rutin, sehingga strategi untuk memecahkan masalah mungkin tidak bisa muncul secara langsung, dan membutuhkan tingkat kreativitas dan orisinalitas yang tinggi dari siswa (Artika \& Karso, 2019; Rahmawati, 2018; Septian, 2017; Septian, Komala, \& Komara, 2019). Siswa dituntut lebih memahami soal dengan artian siswa mengetahui informasi apa saja yang ada pada soal, apa yang diminta soal. Setelah mengetahui itu semua siswa harus bisa menggunakan konsepkonsep yang telah dipelajarinya untuk mengerjakan soal tersebut.

Sejalan dengan penelitian yang dilakukan oleh Putri, A (2018) tentang Analisis Kemampuan Pemecahan Masalah Rutin dan Non-rutin pada Materi Aturan Pecahan diperoleh bahwa terdapat perbedaan kemampuan pemecahan masalah siswa ketika mengejakan soal rutin dan soal non-rutin. Pada masalah rutin, siswa sangat baik dalam menyelesaikann soal, sedangkan pada masalah non-rutin siswa harus mengkonstruksi kembali soal kedalam model matematika.

\section{KESIMPULAN}

Kemampuan pemahaman konsep siswa masih kurang. Siswa belum memenuhi indikator pertama dan ketiga dalam pemahaman konsep. Pada indikator pertama yaitu mampu menerangkan secara verbal mengenai apa yang telah dicapainya siswa telah mampu menyebutkan sifat-sifat bangun datar tersebut secara umum, namun dalam menuliskan sifat-sifat tersebut siswa belum menuliskannya secara lengkap. Sedangkan indikator pemahamn konsep yang ketiga yaitu mampu mengembangkan konsep yang telah dipelajari. Dari hasil jawaban siswa terlihat bahwa siswa telah mampu mengerjakan soal dengan baik, namun terdapat sedikit kesalahan dalam perkalian.

Siswa telah memenuhi indikator kedua pemahaman konsep. Indikator kedua pemahaman konsep yaitu mampu memberikan contoh kontra dari konsep yang telah dipelajari. Siswa mampu menyebutkan contoh kontra yang ada dalam kehidupan berkaitan dengan soal. Hal ini berarti bahwa siswa mampu mengungkapkan matematika dalam kehidupannya.

\section{REFERENSI}

Artika, T., \& Karso, K. (2019). Meningkatkan Kemampuan Pemecahan Masalah Matematis Siswa Dengan Menggunakan Metode Pembelajaran Thinking Aloud Pair Problem Solving (Tapps). Prisma, 8(2), 191-200. 
https://doi.org/10.35194/jp.v8i2.791

Bahar, E. Ekafitria. (2012). Analisis Pemahaman Mahasiswa terhadap Konsep Sistem Persamaan Linear Dua Variabel di Satu TItik. Tesis. Universitas Negeri Makassar: Makassar.

Creswell, J.W. (2010). Research Design Pendekatan Kualitatif, Kuantitatif, dan Mixed Method.

Dafril, A. (2011). Pengaruh Pendekatan Konstruktivisme terhadap Peningkatan Pemahaman Matematika Siswa. Prosiding PGRI. Palembang. [Online] Tersedia di http://mediaharja.blogspot.com/2012/06/penerapan-model-pembelajarancooperatif.html, diakses 25 mei 2020.

Fadhila, E, H., Dwina, F., \& Murni, D. (2014). Penerapan Strategi REACT dalam Meningkatkan Kemampuan Pemahaman Konsep Matematika Siswa Kelas X SMAN 1 Batang Anai. Jurnal Pendidikan Matematika, 3 (1), Jurnal Pendidikan Matematika, 3 (2), 26-30.

Fitria, M., Kartasasmita, B., \& Supianti, I. I. (2019). Analisis Kemampuan Pemahaman Konsep Matematis Siswa yang Menggunakan Model Pembelajaran Reciprolcal Teaching. Jurnal Prisma, 8(2), 124-134

Hamalik, O. (2008). Perencanaan Pengajaran Berdasarkan Pendekatan Sistem. Bumi Aksara: Jakarta.

Hendriana, H, dkk. (2017). Hard Skills and Soft Skills Matematika Siswa. PT. Refika Aditama: Bandung.

Kusumaningtyas, \& Isti Hardiyanti. (2013). Upaya Meningkatkan Pemahaman Konsep Matematika melalui Pendekatan Problem Solving.

Puti, P, M. (2012). Pemahaman Konsep Matematika pada Materi Turunan melalui Pembelajaran Teknik Probing. Jurnal: Pendidikan Matematika, I (1), hlm. 3-6.

Putri, A. (2018). Analisis Kemampuan Pemecahan Masalah Rutin dan Non-rutin pada Materi Aturan Pecahan. Jurnal Pendidikan Tambusai, Vol. 2 No. 4.

Rahmawati, N. I. (2018). Pemanfaatan ICT dalam Meningkatkan Kemampuan Literasi Matematika. PRISMA, 1, 381-387

Ruslan, dkk. (2017). Deskripsi Pemahaman Konseptual Matematika Siswa SMP IT Wahdah Islamiyah pada Materi Pecahan Ditinjau dari Gaya Belajar Visual. Jurnal Issues in Mathematics Education, Vol. 1 No. 21 Hal 21 - 17.

Sagala, S. (2006). Konsep dan Makna Pembelajaran. Alfabeta: Bandung.

Sanjaya, W. (2009). Penelitian Tindakan Kelas. Kencana: Jakarta.

Santrock, John W. (2007). Psikologi Pendidikan. Kencana:Jakarta.

Septian, A. (2017). Penerapan Geogebra untuk Meningkatkan Kemampuan Pemecahan Masalah Matematis Mahasiswa Program Studi Pendidikan Matematika Universitas Suryakancana. PRISMA, 6(2). https://doi.org/10.35194/jp.v6i2.212

Septian, A., Komala, E., \& Komara, K. A. (2019). Pembelajaran dengan Model Creative Problem Solving (CPS) untuk Meningkatkan Kemampuan Berpikir Kreatif Matematis Siswa. Jurnal Prisma Universitas Suryakancana.

Suwarman, R. F. (2018). Analisis Tingkat Kemampuan Pemahaman Konsep Mahasiswa pada Mata Kuliah Pemrograman Komputer. PRISMA, VII(2), 227-237Susanto, A. (2015). Teori Belajar dan Pembelajaran di Sekolah Dasar. Prenada-media Group, Jakarta.

Winkel. (2004). Psikologi Pengajaran. Media Abadi: Yogyakarta. 